\title{
GLACIOLOGICAL STUDIES IN ICELAND WITH ERTS-I IMAGERY*
}

\author{
By Richard S. Williams, Jr. \\ (U.S. Geological Survey, EROS Program Office, Reston, Virginia 22092, U.S.A.) \\ Ágúst BöĐvarsson \\ (Landmælingar Íslands, Reykjavík, Iceland) \\ Sigurjón Rist, Kristján S æmundsson \\ (Orkustofnun Ríkisins, Reykjavík, Iceland) \\ and Sigurdur Thorarinsson \\ (Raunvísindastofnun Háskolans, Reykjavík, Iceland)
}

Abstracr. Under a long-term, bi-national, multi-disciplinary research project between the U.S. Geological Survey and various Icelandic scientific organizations, MSS imagery from the ERTS-I satellite is being used to study the varied dynamic environmental phenomena of Iceland, including its glaciers and ice caps. Initial analysis of the ERTS-I imagery has shown the importance of the repetitive imagery to:

(I) Record relatively short-term glaciological changes. According to measurements made on two ERTS-I images, taken I I months apart, an outlet glacier in the north-east part of Vatnajökull, had surged I.8 km. A combination of field observations and analysis of ERTS imagery shows a total surge in excess of $3 \mathrm{~km}$ which probably took place in a few months, perhaps in as little as a few weeks. Contorted moraines on another of Vatnajökull's outlet glaciers, Skeiðarárjökull, on the south-east coast, show a movement of $600 \mathrm{~m}$ in an I I month period even though the snout of the glacier remained in essentially the same position.

Several glacier-margin lakes have been observed to change in size during the year (197273), particularly Grænalón, which continued to enlarge in area each time it was imaged until its size diminished markedly after a jökulhlaup partially emptied the lake in August 1973. Seasonal changes in the size of sediment plumes along the coast, where glacial rivers debouch their sediment-laden water into the ocean, can also be observed in a time-lapse manner.

(2) Furnish the data necessary to revise certain glaciological features on maps, and to produce ortho-image maps of ice caps directly from ERTS imagery, at least to map scales of I : 250 ooo. Sufficient ERTS-I imagery of Iceland from the late summer and early fall of 1973 now exists to map accurately, from a planimetric standpoint, $90 \%$ of that area of Iceland covered by glacial ice (previously estimated to be $11.5 \%$ of total area of Iceland). Optimum imagery (minimum snow cover, maximum exposure of glacial ice) has been obtained of Vatnajökull, Langjökull, Hofsjökull, Mýrdalsjökull, and Eyjafjallajökull or five (including the four biggest) of the seven largest ice caps in Iceland and five of the smaller (less than $5 \mathrm{o} \mathrm{km}^{2}$ ) ice caps as well. On 19 August ${ }_{9} 973$ Hofsjökull had an area of $9 \mathrm{I}_{5} \mathrm{~km}^{2}$ on ERTS imagery. Its area has usually been cited as $996 \mathrm{~km}^{2}$. On a 1945 Danish Geodetic Institute map ( $1: 500$ ooo) the area is $98 \mathrm{r} \mathrm{km}^{2}$; U.S. Army maps ( $1: 250000$, r969) show an area of $943 \mathrm{~km}^{2}$.

\footnotetext{
* Publication authorized by the Director, U.S. Geological Survey.
} 
(3) Map subglacial volcanic and structural features. Within or at the margins of the ice caps and outlet glaciers, a number of new glaciological, structural, and volcanic features can be mapped from ERTS-I imagery, particularly at low solar illumination angles $\left(<10^{\circ}\right)$ including several probable subglacial central volcanoes, calderas, and tectonic lineaments. Some of the effects of jökulhlaups can be mapped, including subsidence cauldrons resulting from subglacial volcanic or intense geothermal activity.

\title{
THE REMOTE SENSING OF AVALANCHE VICTIMS: PROBLEMS AND PROGRESS
}

\author{
By WiLfried Fritzsche \\ (Institut für Elektronik, Technische Hochschule in Graz, Inffeldgasse I2, A-8o 1o Graz, \\ Austria)
}

Abstract. This paper reviews possible uses of remote-sensing techniques to locate avalanche victims. Until recently probes and dogs were the only methods available, but recently attempts have been made to devise other methods for finding human beings in snow. Ideally such a search should be made possible for other members of the party, as the chance of survival of a victim falls rapidly with increasing time to rescue. For this all members of the party need to have something which the others can locate. The most usual proposal is an electromagnetic transmitter/receiver set. The merits of various possible frequencies are discussed. International agreement on a frequency is urgently required. Magnetic devices might be considered, but the detecting devices are too expensive or heavy to be generally carried. Search parties can of course be equipped with more sophisticated apparatus, and various possibilities are discussed for identifying metal on the victim, for identifying him by radio sounding, for locating him by mapping microwave emission, or for searching for eddy currents induced in him.

\section{DISCUSSION}

J. W. GLEN : Can the magnets in compasses for mountaineers be made strong enough to be usable for easy detection?

W. Fritzsche: Unfortunately not.

M. DE Quervain: Also I believe the magnetometers did not have sufficient range to be effective.

Fritzsche: This is true, but magnetic methods have not been developed to their full potential. One of the main reasons more work has not been done on them is that it seems to be impossible to develop a device like the transmitter-receiver system that will be cheap enough to distribute to all touring groups. The Förster (second harmonic) procedure was affected by temperature, and the Skifinder has problems of read-out among other things. The Skifinder and the equipment built in the Technische Hochschule Graz which are sufficiently sensitive to detect magnets to a depth of $3 \mathrm{~m}$ consist of a left and right strip each of $5 \mathrm{~m}$ width- $\mathrm{Io} \mathrm{m}$ in all. This is described in the doctoral dissertation of A. Etschmaier, Technische Hochschule Graz, ig69. 